\title{
Association between environmental particulate matter and arterial stiffness in patients undergoing hemodialysis
}

\author{
Cheng-Hao Weng ${ }^{1,3}$, Ching-Chih Hü ${ }^{2,3}$, Tzung-Hai Yen ${ }^{1,3}$ and Wen-Hung Huang ${ }^{1,3^{*}}$
}

\begin{abstract}
Background: Aortic pulse wave velocity (PWV) has been shown to be an independent predictor of cardiovascular mortality in patients with end-stage renal disease and the general population. Atmospheric particulate- matter (PM) concentrations and their effects on cardiovascular system by affecting arterial stiffness and central hemodynamic parameters had been noted. The purpose of this study was to access the correlation of air pollution variables and PWV in patients undergoing hemodialysis (HD).

Methods: This study analyzed $127 \mathrm{HD}$ patients treated at the outpatient HD center. Brachial-ankle pulse wave velocity (baPWV) was measured by using a Vascular Profiler 1000 (VP-1000). Air pollution levels were recorded by a network of 27 monitoring stations near or in the patients' living areas throughout Taiwan. The 12-month average concentrations of PM with an aerodynamic diameter of $<10$ and $<2.5 \mathrm{~mm}\left(\mathrm{PM}_{10}\right.$ and $\mathrm{PM}_{2.5}$, respectively), sulfur dioxide $\left(\mathrm{SO}_{2}\right)$, nitrogen dioxide $\left(\mathrm{NO}_{2}\right)$, carbon monoxide $(\mathrm{CO})$, and ozone $\left(\mathrm{O}_{3}\right)$ were included.
\end{abstract}

Results and Discussion: Multivariate linear regression analyses indicated that systolic blood pressure (SBP) $(\beta=0.589$, $P<0.025)$, age $(\beta=0.316, P<0.001)$, serum aluminum level $(A I)(\beta=0.149, P=0.020)$, and $P_{10}(\beta=0.133, P=0.036)$ were positively correlated with baPW.

Conclusion: This cross-sectional study shows that in HD patients, the environmental $\mathrm{PM}_{10}$ level is associated with the baPW.

Keywords: Hemodialysis, Pulse wave velocity, Particulate matter

\section{Background}

Patients with end-stage renal disease undergoing hemodialysis (HD) have high rates of morbidity and mortality. Cardiovascular diseases account for almost half of this mortality [1]. Aortic pulse wave velocity (PWV) has been shown to be an independent predictor of cardiovascular mortality in patients with end-stage renal disease and the general population [2]. Brachial-ankle pulse wave velocity (baPWV) is an accurate indicator of aortic PWV measured by intra-aortic catheter by volume-rendering [3]. We have previous shown that serum aluminum level

\footnotetext{
* Correspondence: williammedia@yahoo.com.tw

'Department of Nephrology, Chang Gung Memorial Hospital, Linkou, 5 Fu-Shin Street, Kwei-Shan 333, Taoyuan, Taiwan

${ }^{3}$ College of Medicine, Chang Gung University, Taoyuan, Taiwan

Full list of author information is available at the end of the article
}

(Al) was positively associated with baPWV after correction of other known risk factors [4]. Adamopoulos et al. [5] analyzed the atmospheric pollution variables, including atmospheric particulate- matter (PM) concentrations and their effects on cardiovascular system by affecting arterial stiffness and central hemodynamic parameters, and found that in men, $\mathrm{PM}_{10}$ air pollution levels were associated with heightened amplitude of PWV. Our recently study also showed that variables of air pollution levels were associated with 2-year mortality, level of high sensitivity C-reactive protein (hsCRP), and dialysis related infections in patients undergoing peritoneal dialysis [6-8]. The purpose of this study was to access the correlation of air pollution variables and baPWV in patients undergoing HD, which had never been studied before.

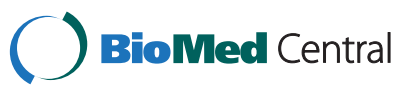




\section{Methods}

\section{Ethics statement}

This study complied with the guidelines of the Declaration of Helsinki and was approved by the Medical Ethics Committee of Chang Gung Memorial Hospital (Institutional Review Board approval number: 101-5199B), a tertiary referral center located in the northern part of Taiwan. Written informed consent for this cross-sectional and publication of these data were obtained from every patient. All data were protected securely and only available to researchers; the data were also analyzed without patients' names.

\section{Subjects}

One hundred and thirty eight HD patients treated at the outpatient HD center at Chang Gung Memorial Hospital in Taoyuan, Taiwan were analyzed. To diagnose peripheral arterial occlusive disease (PAOD), the ankle-brachial blood pressure index (ABPI) was developed. PAOD has a reliable and accepted marker, which is when ABPI is less than 0.9. Severe PAOD decreases baPWV due to decreased internal pressure and blood flow. Therefore, eleven patients with ABPI less than 0.9 were excluded. The analysis enrolled 127 patients. The ESRD patients were enrolled if they were on HD for more than 3 months. Medical and demographic data were collected by chart reviews and the online database at our hospital. Regular clinical survey for all patients within one month of enrollment included serum creatinine, albumin, triglyceride and cholesterol immediately before HD. Average HD session in these patients was 4 hours and three times weekly. Our HD units use water treated by reverse osmosis. Water quality, including aluminum level less than $0.01 \mathrm{ppm}$, was proved by water analysis annually. The definition of hypotension was systolic blood pressure $<90 \mathrm{mmHg}$. The definition of intradialytic hypotension was one or more episodes of hypotension during each HD session. The definition of always hypotension was that patients had hypotension measured immediately before every HD session and throughout the entire HD session. Routine clinical workup for all patients was checked within 1 month of baPWV measurement.

\section{Brachial-ankle pulse wave velocity (baPWV) and ABPI measurement}

Brachial-ankle pulse wave velocity and ABPI were measured by a Vascular Profiler 1000 (VP-1000) (Colin Corporation, Japan) as previously described in our study [3, 9]. Demographic data (birthday, height, weight and gender) were entered into the device. The HD patients were measured one hour before HD. After HD, baPWV does not change, or even rises. Fluid reduction by HD does not affect PWV significantly [10]. After at least $10 \mathrm{mi}-$ nutes of rest, the patients were placed in a supine position, and the value of baPWV was auto-calculated and used for analysis. This profiler records baPWV, ABPI, brachial and tibial SBP, diastolic blood pressure, pulse pressure, electrocardiogram, and phonocardiogram simultaneously. The baPWV was calculated using the equation: baPWV = $(\mathrm{D} 1-\mathrm{D} 2) / \mathrm{t}$, where $\mathrm{D} 1$ is the distance between heart and ankle, D2 is the distance between heart and brachium, and $t$ is the transit time between brachial arterial waves and tibial arterial waves. The ABPI was calculated as the following equation: ankle systolic pressure/arm systolic pressure. The dates of baPWV measurement were between March $1^{\text {st }}, 2014$ to June $30^{\text {th }}, 2014$. Mean arterial pressure (MAP) is widely recognized to be a determinant of arterial stiffness and we used MAP adjusted baPWV for analysis. Adjustment was performed by a linear regression of the MAP and baPWV. The residual values were then added to unadjusted baPWV to form the adjusted baPWV.

\section{Definition of normal and abnormal baPWV}

Because there was no previous data to define the normal range of baPWV in dialysis patients, we used the reference values stated in the study by Chuang et al. [11], which showed the age and gender stratified normal reference values of baPWV derived from men and women without any of the cardiovascular risk factors for the metabolic syndrome in a community. The definition of the normal baPWV was baPWV lower than or equal to the upper limit of the reference values and the definition of abnormal baPWV was baPWV higher than the reference values.

\section{Air quality status and analysis}

Levels of air pollution were recorded as described in our previous study [7] by a network of 26 monitoring stations near the patients' living areas in Taiwan. Data from the database on the air quality status of Taiwan Air Quality Monitoring Network were analyzed. Due to no previous survey focused on this issue, the previous average exposure of 365 days concentration of PMs, based on the date of baPWV measurement, was used for each subject. Previous 12-month average concentrations of PM with PM with an aerodynamic diameter of $<10$ and $<2.5 \mathrm{~mm}\left(\mathrm{PM}_{10}\right.$ and $\mathrm{PM}_{2.5}$, respectively), sulfur dioxide $\left(\mathrm{SO}_{2}\right)$, nitrogen dioxide $\left(\mathrm{NO}_{2}\right)$, carbon monoxide $(\mathrm{CO})$, and ozone $\left(\mathrm{O}_{3}\right)$ were included as reference items. Air pollution levels were recorded by a network of 27 monitoring stations near or in the patients' living areas throughout Taiwan. Therefore, the average of approximately $8760(24 \times 365=8760)$ pieces of data for every monitoring station were calculated. The reference items were generally obtained from monitoring stations in the same area. If a patient lived between 2 monitoring stations, we selected the air pollutant data from the nearest 
station for analysis. If there is no monitoring station in a patient's living district, we selected the reference from the nearest station $(<15 \mathrm{~km})$.

\section{Statistical analysis}

Mean \pm standard deviation or number and percentage in parentheses, unless otherwise stated, were used to express data. Normal distribution using the Kolmogorov-Smirnov test was tested for all variables. To compare the means of continuous variables and normally distributed data, the Student's $t$ test was used and the Mann-Whitney U test was used for non-normally distributed data. The chi-square test was used to analyze categorical data. Univariate linear regression analysis risk was used to assessed risk factors, and statistically significant variables $(P<0.05)$ were included in a multivariate analysis by applying a forward elimination multiple linear regression. All statistical tests were 2-tailed, with $P$ values $<0.05$ being considered statistically significant. Data were analyzed using SPSS 12.0 software (SPSS, Inc., Chicago, IL).

\section{Results}

\section{Subject characteristics}

A total of 127 patients from a single HD center were enrolled in this study. Table 1 lists the characteristics of the study subjects (mean age, $58.5 \pm 9.9$ years). Of all patients, 52 were male. The median baPWV was $1767.2 \pm$ $651.5 \mathrm{~cm} / \mathrm{s}$. The median concentration of $\mathrm{NO}_{2}$ was $22.9 \pm$ $3.8 \mathrm{ppb} ; \mathrm{CO}, 0.6 \pm 0.2 \mathrm{ppm} ; \mathrm{SO}_{2}, 6.9 \pm 2.1 \mathrm{ppb} ; \mathrm{PM}_{10}$, $57.9 \pm 5.7 \mathrm{mg} / \mathrm{m}^{3} ; \mathrm{PM}_{2.5}, 31.8 \pm 2.8 \mathrm{mg} / \mathrm{m} 3 ; \mathrm{O}_{3}, 25.9 \pm$ $2.9 \mathrm{ppb}$; and NO, $10.1 \pm 7.8 \mathrm{ppb}$. Because distribution of triglyceride, intact parathyroid hormone (iPTH), $\mathrm{Al}$ and high sensitivity C-reactive protein (hsCRP) were skewed, they were log-transformed for further analysis.

We divided the patients into 2 groups, normal baPWV and abnormal baPWV. There were 59 patients in the normal baPWV group and 68 patients in the abnormal baPWV group. The levels of age, baPWV, SBP and hsCRP, and percentage of male, and DM were significantly higher in abnormal baPWV group. The percentage of intradialytic hypotension, and always hypotension were significantly higher in normal baPWV group (Table 2).

\section{Factors associated with baPWV level in patients undergoing HD}

Univariate linear regression identified several clinical variables that were significantly associated with baPWV. These included fasting glucose $(\beta=0.272, P=0.002)$, gender $(\beta=0.250$, female as reference, $P=0.005)$, age $(\beta=0.375, P<0.001)$, log-transformed $\mathrm{Al}(\log \mathrm{Al})(\beta=$ $0.201, P=0.023)$, diabetes mellitus $(\beta=0.293, P=0.001)$, intradialytic hypotension $(\beta=-0.209, P=0.019)$, log transformed hsCRP (log hsCRP) $(\beta=0.229, P=0.010), \mathrm{SO}_{2}$ $(\beta=0.208, P=0.019)$, heart rate $(\beta=0.545, P=<0.001)$
Table 1 Characteristics of the studied population

\begin{tabular}{|c|c|}
\hline Characteristic & $\begin{array}{l}\text { Studied patients } \\
(n=127)\end{array}$ \\
\hline Age (y) & $58.5 \pm 9.9$ \\
\hline Male sex (\%) & 40.9 \\
\hline baPW $(\mathrm{cm} / \mathrm{s})$ & $1767.2 \pm 651.5$ \\
\hline DM (\%) & 23.6 \\
\hline Inradialytic hypotension (\%) & 20.5 \\
\hline Always hypotension (\%) & 3.9 \\
\hline HDF (\%) & 16.5 \\
\hline $\mathrm{Hb}(\mathrm{g} / \mathrm{dL})$ & $10.5 \pm 1.3$ \\
\hline $\mathrm{BUN}(\mathrm{mg} / \mathrm{dL})$ & $64.7 \pm 15.8$ \\
\hline $\mathrm{Cr}(\mathrm{mg} / \mathrm{dL})$ & $10.8 \pm 2.4$ \\
\hline $\mathrm{Na}(\mathrm{mEq} / \mathrm{L})$ & $139.8 \pm 3.1$ \\
\hline $\mathrm{K}(\mathrm{mEq} / \mathrm{L})$ & $4.8 \pm 0.7$ \\
\hline Calcium (mg/dL) & $9.8 \pm 1.0$ \\
\hline Phosphorous (mg/dL) & $4.6 \pm 1.4$ \\
\hline Calcium-phosphorous product (mg/dL)2 & $46.0 \pm 16.3$ \\
\hline Alb (g/dL) & $4.1 \pm 0.3$ \\
\hline Total cholesterol (mg/dL) & $185.3 \pm 38.6$ \\
\hline Triglyceride (mg/dL) & $211.86 \pm 157.37$ \\
\hline Ultrafiltration amount per dialysis session (L) & $2.3 \pm 1.1$ \\
\hline $\mathrm{SBP}(\mathrm{mmHg})$ & $139.2 \pm 27.0$ \\
\hline $\mathrm{ABI}$ & $1.0 \pm 0.1$ \\
\hline $\mathrm{TB} \mid$ & $0.7 \pm 0.1$ \\
\hline Body Mass Index $\left(\mathrm{kg} / \mathrm{m}^{2}\right)$ & $22.6 \pm 3.5$ \\
\hline iPTH (pg/mL) & $191.3 \pm 219.2$ \\
\hline Urea reduction rate & $0.8 \pm 0.1$ \\
\hline $\mathrm{Kt} / \mathrm{N}$ & $1.8 \pm 0.3$ \\
\hline Net protein catabolic rate (g/day/kg body weight) & $1.2 \pm 0.4$ \\
\hline Aluminum (ng/mL) & $10 \pm 8$ \\
\hline Hemodialysis duration (months) & $72.5 \pm 61.8$ \\
\hline hsCRP (mg/L) & $4.7 \pm 6.4$ \\
\hline $\mathrm{NO}_{2}(\mathrm{ppb})$ & $22.9 \pm 3.8$ \\
\hline $\mathrm{CO}(\mathrm{ppm})$ & $0.6 \pm 0.2$ \\
\hline $\mathrm{SO}_{2}(\mathrm{ppb})$ & $6.9 \pm 2.1$ \\
\hline $\mathrm{PM}_{10}\left(\mathrm{ug} / \mathrm{m}^{3}\right)$ & $57.9 \pm 5.7$ \\
\hline PM2.5 $\left(\mathrm{ug} / \mathrm{m}^{3}\right)$ & $31.8 \pm 2.8$ \\
\hline $\mathrm{O}_{3}(\mathrm{ppb})$ & $25.9 \pm 2.9$ \\
\hline NO (ppb) & $10.1 \pm 7.8$ \\
\hline
\end{tabular}

$D M=$ diabetes mellitus, $H D F=$ hemodiafiltration, $H b=$ hemoglobulin, $B U N=$ blood urea nitrogen, $C r=$ creatinine, $K=$ potassium, $S B P=$ systolic blood pressure, $A l b=$ albumin, $A B I=$ ankle brachial index, $T B I=$ tibial brachial index, $i P T H=$ intact parathyroid hormone, $K t / N=$ a number used to quantify hemodialysis treatment adequacy, $A l=$ aluminum, $h s C R P=$ high sensitivity $\mathrm{C}$ reactive protein, $\mathrm{NO}_{2}=$ environmental nitrogen dioxide, $\mathrm{CO}=$ environmental carbon dioxide, $\mathrm{SO}_{2}=$ environmental sulfur dioxide, $P M_{10}=$ particulate matter with aerodynamic diameter $<10 \mathrm{~mm}, P M_{2.5}=$ particulate matter with aerodynamic diameter $<2.5 \mathrm{~mm}, \mathrm{O}_{3}=$ environmental ozone, $\mathrm{NO}=$ environmental nitrogen oxide 
Table 2 Characteristics of the normal and abnormal PWV patients

\begin{tabular}{|c|c|c|c|}
\hline \multirow[t]{2}{*}{ Characteristic } & \multicolumn{3}{|c|}{ Studied patients $(n=127)$} \\
\hline & $\begin{array}{l}\text { Normal PWV } \\
(\mathrm{n}=59)\end{array}$ & $\begin{array}{l}\text { Abnormal PWV } \\
(\mathrm{n}=68)\end{array}$ & $P$ \\
\hline Age (y) & $56.4 \pm 10.9$ & $60.3 \pm 8.7$ & 0.032 \\
\hline Male sex (\%) & 30.5 & 48.5 & 0.039 \\
\hline baPWV (cm/s) & $1247.2 \pm 292.0$ & $2218.4 \pm 528.7$ & $<0.001$ \\
\hline DM (\%) & 10.2 & 35.3 & 0.001 \\
\hline Inradialytic hypotension (\%) & 34.5 & 8.8 & $<0.001$ \\
\hline Always hypotension (\%) & 8.8 & 0 & 0.013 \\
\hline HDF (\%) & 18.6 & 14.7 & 0.551 \\
\hline $\mathrm{Hb}(\mathrm{g} / \mathrm{dL})$ & $10.5 \pm 1.4$ & $10.5 \pm 1.3$ & 0.744 \\
\hline BUN (mg/dL) & $65.0 \pm 15.7$ & $64.5 \pm 16.1$ & 0.864 \\
\hline $\mathrm{Cr}(\mathrm{mg} / \mathrm{dL})$ & $11.1 \pm 2.1$ & $10.6 \pm 2.7$ & 0.223 \\
\hline $\mathrm{Na}(\mathrm{mEq} / \mathrm{L})$ & $139.6 \pm 3.2$ & $140.0 \pm 3.1$ & 0.518 \\
\hline $\mathrm{K}(\mathrm{mEq} / \mathrm{L})$ & $4.8 \pm 0.7$ & $4.9 \pm 0.6$ & 0.511 \\
\hline Calcium (mg/dL) & $9.7 \pm 1.0$ & $9.9 \pm 1.0$ & 0.276 \\
\hline Phosphorous (mg/dL) & $4.6 \pm 1.5$ & $4.6 \pm 1.4$ & 0.815 \\
\hline $\begin{array}{l}\text { Calcium-phosphorous product } \\
(\mathrm{mg} / \mathrm{dL}) 2\end{array}$ & $46.7 \pm 16.5$ & $45.4 \pm 16.2$ & 0.667 \\
\hline Alb (g/dL) & $4.0 \pm 0.2$ & $4.1 \pm 0.4$ & 0.429 \\
\hline Total cholesterol (mg/dL) & $180.5 \pm 39.1$ & $189.4 \pm 38.0$ & 0.199 \\
\hline Triglyceride (mg/dL) & $195.5 \pm 130.0$ & $226.1 \pm 177.5$ & 0.276 \\
\hline $\begin{array}{l}\text { Ultrafiltration amount per } \\
\text { dialysis session }(\mathrm{L})\end{array}$ & $2.5 \pm 1.2$ & $2.0 \pm 0.9$ & 0.017 \\
\hline $\mathrm{SBP}(\mathrm{mmHg})$ & $129.2 \pm 29.3$ & $147.9 \pm 21.5$ & $<0.001$ \\
\hline$A B \mid$ & $1.00 \pm 0.15$ & $1.05 \pm 0.12$ & 0.055 \\
\hline $\mathrm{TBI}$ & $0.72 \pm 0.16$ & $0.73 \pm 0.15$ & 0.545 \\
\hline Body Mass Index $\left(\mathrm{kg} / \mathrm{m}^{2}\right)$ & $22.6 \pm 3.1$ & $22.5 \pm 3.4$ & 0.916 \\
\hline iPTH (pg/mL) & $188.6 \pm 201.9$ & $193.7 \pm 234.6$ & 0.898 \\
\hline Urea reduction rate & $0.78 \pm 0.06$ & $0.78 \pm 0.06$ & 0.747 \\
\hline $\mathrm{Kt} / \mathrm{V}$ & $1.8 \pm 0.3$ & $1.8 \pm 0.4$ & 0.655 \\
\hline $\begin{array}{l}\text { Net protein catabolic rate } \\
\text { (g/day/kg body weight) }\end{array}$ & $1.2 \pm 0.4$ & $1.2 \pm 0.4$ & 0.946 \\
\hline $\mathrm{Al}(\mathrm{ng} / \mathrm{mL})$ & $8.8 \pm 5.7$ & $10.4 \pm 8.9$ & 0.232 \\
\hline $\begin{array}{l}\text { Hemodialysis duration } \\
\text { (months) }\end{array}$ & $78.7 \pm 67.8$ & $67.2 \pm 56.0$ & 0.298 \\
\hline hsCRP (mg/L) & $3.4 \pm 3.5$ & $5.8 \pm 7.7$ & 0.023 \\
\hline $\mathrm{NO}_{2}(\mathrm{ppb})$ & $22.9 \pm 3.6$ & $22.9 \pm 4.0$ & 0.984 \\
\hline $\mathrm{CO}(\mathrm{ppm})$ & $0.63 \pm 0.17$ & $0.64 \pm 0.22$ & 0.890 \\
\hline $\mathrm{SO}_{2}(\mathrm{ppb})$ & $6.7 \pm 2.0$ & $7.2 \pm 2.1$ & 0.184 \\
\hline $\mathrm{PM}_{10}\left(\mathrm{ug} / \mathrm{m}^{3}\right)$ & $57.2 \pm 5.4$ & $58 . \pm 5.9$ & 0.226 \\
\hline $\mathrm{PM}_{2.5}\left(\mathrm{ug} / \mathrm{m}^{3}\right)$ & $31.6 \pm 2.9$ & $31.9 \pm 2.8$ & 0.513 \\
\hline
\end{tabular}

and $\mathrm{PM}_{10}(\beta=0.205, P=0.021)$. Multivariate linear regression analyses indicated that heart rate $(\beta=0.433, P<$ $0.001)$, intradialytic hypotension $(\beta=-0.198, P=0.006)$, age $(\beta=0.193, P=0.013), \log \mathrm{Al}(\beta=0.144, P=0.045)$, and $\mathrm{PM}_{10}(\beta=0.150, P=0.035)$ were positively correlated with baPWV (Table 3).

\section{Discussion}

The purpose of the present study was to assess the cross sectional relations between clinical variables, ambient $\mathrm{PM}_{10}$ concentrations, and baPWV in HD patients. The main findings of the present study were that: $\mathrm{PM}_{10}$, age, $\mathrm{Al}$ and SBP were independently correlated with baPWV and higher concentrations of ambient $\mathrm{PM}_{10}$ was associated with a higher magnitude of baPWV.

This study is the first to show that environmental $\mathrm{PM}_{10}$ is positively associated with baPWV in HD patients. Particulate matter inhalation has been associated with acute arterial vasoconstriction in healthy adults [12], disrupting systolic function [13], heart rate variability [14], and persistent lung inflammation and endothelial dysfunction [15], factors that may increase the PWV. Automobile emissions are the most important source of $\mathrm{PM}_{10}$ in the urban areas, followed by crustal materials, secondary aerosols, biomass burning, industrial emissions and marine spray in Taiwan [16]. Lanqrishet et al. [17] showed that following exposure to diesel exhaust, $\mathrm{N}(\mathrm{G})$-monomethyl-l-arginine (l-NMMA), a NO synthase inhibitor, caused increase in blood pressure and arterial stiffness. Graff et al. [18] demonstrated that after 2hours of exposure to crustal materials, mild pulmonary inflammation, decreased tissue plasminogen activator, and decreased heart rate variability. Heo et al. [19] showed that particles derived from mobile sources (i.e., gasoline and diesel emissions) and biomass burning were associated with respiratory mortality and cardiovascular mortality, respectively. The cardiovascular mortality may be due to the increased PWV as observed in our study. Ambient $\mathrm{PM}_{10}$ exposure had also been reported to induce 
Table 3 Linear regression analysis with baPWV as the dependent variable

\begin{tabular}{|c|c|c|c|c|}
\hline \multirow[t]{2}{*}{ Variable } & \multicolumn{2}{|c|}{ Unstandardized coefficients } & \multirow{2}{*}{$\begin{array}{l}\text { Standardized coefficients } \\
\text { Beta }\end{array}$} & \multirow[t]{2}{*}{$P$ value } \\
\hline & B & Std. error & & \\
\hline \multicolumn{5}{|l|}{ Univariate } \\
\hline Fasting glucose (mg/dL) & 2.758 & 0.873 & 0.272 & 0.002 \\
\hline Gender (female as reference group) & 330.763 & 114.639 & 0.250 & 0.005 \\
\hline Age (y) & 24.567 & 5.426 & 0.375 & $<0.001$ \\
\hline Log Al (ng/mL) & 417.573 & 181.613 & 0.201 & 0.023 \\
\hline DM & 447.395 & 130.649 & 0.293 & 0.001 \\
\hline Intra-dialytic hypotension & -334.493 & 140.764 & -0.209 & 0.019 \\
\hline $\log$ hsCRP (mg/L) & 308.112 & 116.982 & 0.229 & 0.010 \\
\hline $\mathrm{SO}_{2}(\mathrm{ppb})$ & 65.722 & 27.617 & 0.208 & 0.019 \\
\hline $\mathrm{PM}_{10}\left(\mathrm{ug} / \mathrm{m}^{3}\right)$ & 23.512 & 10.043 & 0.205 & 0.021 \\
\hline Heart rate (/min) & 33.727 & 4.647 & 0.545 & $<0.001$ \\
\hline Log triglyceride (mg/dL) & 60.834 & 199.684 & 0.027 & 0.761 \\
\hline $\mathrm{Hb}(\mathrm{g} / \mathrm{dL})$ & 12.615 & 44.066 & 0.026 & 0.775 \\
\hline Alb $(g / d L)$ & -76.401 & 179.385 & -0.038 & 0.671 \\
\hline Total cholesterol (mg/dL) & -0.373 & 1.510 & -0.022 & 0.805 \\
\hline Calcium (mg/dL) & 27.205 & 59.121 & 0.041 & 0.646 \\
\hline Phosphorous (mg/dL) & -56.563 & 40.098 & -0.125 & 0.161 \\
\hline Calcium-phosphorous product (mg/dL)2 & -5.512 & 3.573 & -0.137 & 0.125 \\
\hline Body Mass Index (kg/m²) & 22.999 & 16.460 & 0.124 & 0.165 \\
\hline Urea reduction rate & -1100.164 & 999.288 & -0.098 & 0.273 \\
\hline $\mathrm{Kt} / \mathrm{N}$ & -244.671 & 172.193 & -0.127 & 0.158 \\
\hline Net protein catabolic rate (g/day/kg body weight) & -197.253 & 156.598 & -0.116 & 0.210 \\
\hline Hemodialysis duration (months) & -1.334 & 0.936 & -0.126 & 0.156 \\
\hline $\mathrm{NO}_{2}(\mathrm{ppb})$ & -5.595 & 15.351 & -0.033 & 0.716 \\
\hline $\mathrm{CO}(\mathrm{ppm})$ & -163.429 & 295.340 & -0.050 & 0.581 \\
\hline $\mathrm{PM}_{2.5}\left(\mathrm{ug} / \mathrm{m}^{3}\right)$ & 22.878 & 20.493 & 0.099 & 0.266 \\
\hline $\mathrm{O}_{3}(\mathrm{ppb})$ & 23.474 & 20.080 & 0.104 & 0.245 \\
\hline NO (ppb) & -1.728 & 7.433 & -0.021 & 0.817 \\
\hline ARB/ACEi & 246.279 & 173.512 & 0.216 & 0.158 \\
\hline $\mathrm{CCB}$ & -7.177 & 145.965 & -0.004 & 0.961 \\
\hline Beta blocker & 47.806 & 139.934 & 0.031 & 0.733 \\
\hline \multicolumn{5}{|l|}{ Multivariate } \\
\hline Heart rate (/min) & 26.849 & 4.775 & 0.433 & $<0.001$ \\
\hline Intra-dialytic hypotension & -317.174 & 112.815 & -0.198 & 0.006 \\
\hline Age (y) & 12.615 & 4.978 & 0.193 & 0.013 \\
\hline Log Al (ng/mL) & 297.553 & 146.640 & 0.144 & 0.045 \\
\hline $\mathrm{PM}_{10}\left(\mathrm{ug} / \mathrm{m}^{3}\right)$ & 17.517 & 8.234 & 0.150 & 0.035 \\
\hline
\end{tabular}

$D M=$ diabetes mellitus, $S B P=$ systolic blood pressure, $\log A l=\log$-transformed aluminum, $\log h s C R P=\log$-transformed high sensitivity $C$ reactive protein, Log triglyceride $=\log$-transformed triglyceride, $\mathrm{SO} 2=$ environmental sulfur dioxide, $P M_{10}=$ particulate matter with aerodynamic diameter $<10 \mathrm{~mm}, \mathrm{O}_{3}=$ environmental ozone, $\mathrm{Hb}=$ hemoglobulin, $\mathrm{Al} / \mathrm{b}=$ albumin, $\mathrm{NO}_{2}=$ environmental nitrogen dioxide, $\mathrm{CO}=$ environmental carbon dioxide, $P M_{2.5}=$ particulate matter with aerodynamic diameter $<2.5 \mathrm{~mm}, N O=$ environmental nitrogen oxide, $K t N=$ a number used to quantify hemodialysis treatment adequacy, $A R B=$ angiotensin receptor blocker, $A C E i=$ angiotensin-converting-enzyme inhibitor, $C C B=$ calcium channel blocker

considerable oxidative stress and systemic inflammation in ApoE knockout mice and contributed to the progression of atherosclerosis [20]. Systemic inflammation and atherosclerosis are both predictors of increased PWV [21]. Adamopoulos et al. showed no significant association between environmental variables and arterial stiffness. 
However, in men, the mean 5- day $\mathrm{PM}_{10}$ air concentration was independently associated with the augmentation pressure $[2.0 \mathrm{mmHg}$ ( $95 \%$ confidence interval (CI) $0.56-3.39$ ) per $\left.43.4 \mathrm{mg} / \mathrm{m}^{3}\right]$ and the aortic-pulse pressure $[2.78 \mathrm{mmHg}(95 \% \mathrm{CI} 3.91-5.12)]$ denoting a significant effect of PM on the aortic-wave reflection magnitude and central hemodynamics [5]. In our study, we have demonstrated that $\mathrm{PM}_{10}$ was associated with baPWV, including men and women undergoing HD. The difference between our study and Adamopoulos's might be the more susceptible to the influence by air pollution in HD patients.

In our previous study, we showed that living in Taipei Basin was a risk factor predicting 2-year mortality in elderly HD patients [22]. Air pollution in this crowded area may be the factor that caused this phenomenon. The present study also showed that age was also significantly correlated with baPWV. Therefore, higher PWV caused by $\mathrm{PM}_{10}$ might be a reason for higher 2-year mortality in HD patients living in Taipei Basin area. Our studies also demonstrated that environmental $\mathrm{NO}_{2}$ level was associated with 2-year mortality [8] and environmental $\mathrm{CO}$ level was associated with the level of hsCRP in peritoneal dialysis patients [6].

This study showed that $\mathrm{Al}$ was positively associated with baPWV and the correlation between $\mathrm{Al}$ and baPWV had been discussed in our previous study [4]. In the study by Michael et al. [23], aluminum was one of the components of $\mathrm{PM}_{10}$. Therefore, we calculated the correlation between serum $\mathrm{Al}$ level and $\mathrm{PM}_{10}$ and showed no significant correlation. The serum aluminum of these patients did not come from air pollution and might be due to medication, drinking water, or dissociation from aluminum containers.

\section{Conclusion}

In conclusion, this cross-sectional study showed that in $\mathrm{HD}$ patients, the environmental $\mathrm{PM}_{10}$ level was associated with baPWV.

\footnotetext{
Abbreviations

PWV: Aortic pulse wave velocity; PM: Particulate- matter; HD: Hemodialysis; baPWV: Brachial-ankle pulse wave velocity; $\mathrm{PM}_{10}$ and $\mathrm{PM}_{2.5}$ : An aerodynamic PM diameter of $<10$ and $<2.5 \mathrm{~mm} ; \mathrm{SO}_{2}$ : Sulfur dioxide; $\mathrm{NO}_{2}$ : Nitrogen dioxide; $\mathrm{CO}$ : Carbon monoxide; $\mathrm{O}_{3}$ : Ozone; SBP: Systolic blood pressure; Al: Serum aluminum level; hsCRP: High sensitivity C-reactive protein; ABPI: Ankle-brachial blood pressure index; PAOD: Peripheral arterial occlusive disease.
}

\section{Competing interest}

All authors certify that there is no conflict of interest with any financial organization regarding the material discussed in the manuscript.

\section{Authors' contributions}

Conceived and designed the experiments: WHH, THY, CHW. Performed the experiments: $\mathrm{WHH}, \mathrm{CHW}, \mathrm{CCH}$. Analyzed the data: $\mathrm{WHH}, \mathrm{THY}, \mathrm{CHW}$. Contributed reagents/materials/analysis tools: WHH, THY, CCH. Wrote the paper: $\mathrm{WHH}, \mathrm{CHW}$. All authors read and approved the final manuscript.
Authors' information

Not applicable.

\section{Availability of data and materials}

The original data set can be obtained by mailing the request to our first author (Cheng-Hao Weng, drweng@seed.net.tw) or corresponding author (Wen-Hung Huang, williammedia@yahoo.com.tw).

\section{Acknowledgement}

Cheng-Hao Weng was funded by research grants from the Chang Gung Memorial Hospital, Linkou (CMRPG5D0081).

\section{Author details}

'Department of Nephrology, Chang Gung Memorial Hospital, Linkou, 5 Fu-Shin Street, Kwei-Shan 333, Taoyuan, Taiwan. ${ }^{2}$ Department of Hepatogastroenterology and Liver Research Unit, Chang Gung Memorial Hospital, Keelung, Taiwan. ${ }^{3}$ College of Medicine, Chang Gung University, Taoyuan, Taiwan.

Received: 3 July 2015 Accepted: 21 September 2015

Published online: 06 October 2015

\section{References}

1. Chiu DY, Green D, Abidin N, Sinha S, Kalra PA. Echocardiography in hemodialysis patients: uses and challenges. Am J Kidney Dis. 2014;64(5):804-16.

2. Guerin AP, Pannier B, Marchais SJ, London GM. Cardiovascular disease in the dialysis population: prognostic significance of arterial disorders. Curr Opin Nephrol Hypertens. 2006;15(2):105-10.

3. Yamashina A, Tomiyama H, Takeda K, Tsuda H, Arai T, Hirose K, et al. Validity, reproducibility, and clinical significance of noninvasive brachial-ankle pulse wave velocity measurement. Hypertens Res. 2002;25(3):359-64.

4. Weng $\mathrm{CH}$, Huang WH, Yu CC, Chang CT, Yang CW. Serum aluminum level correlates with arterial stiffness in haemodialysis patients. Int I Clin Pract. 2009;63(2):249-53.

5. Adamopoulos D, Vyssoulis G, Karpanou E, Kyvelou SM, Argacha JF, Cokkinos $D$, et al. Environmental determinants of blood pressure, arterial stiffness, and central hemodynamics. J Hypertens. 2010;28(5):903-9.

6. Huang WH, Yen TH, Chan MJ, Su YJ. Environmental carbon monoxide level is associated with the level of high-sensitivity C-reactive protein in peritoneal dialysis patients. Medicine. 2014;93(26), e181.

7. Huang WH, Yen TH, Chan MJ, Su YJ. Impact of environmental particulate matter and peritoneal dialysis-related infection in patients undergoing peritoneal dialysis. Medicine. 2014;93(25), e149.

8. Lin $\mathrm{JH}$, Yen $\mathrm{TH}$, Weng $\mathrm{CH}$, Huang WH. Environmental NO2 Level is Associated with 2-Year Mortality in Patients Undergoing Peritoneal Dialysis. Medicine. 2015;94(1), e368.

9. Tomiyama H, Yamashina A, Arai T, Hirose K, Koji Y, Chikamori T, et al. Influences of age and gender on results of noninvasive brachial-ankle pulse wave velocity measurement-a survey of 12517 subjects. Atherosclerosis. 2003;166(2):303-9.

10. Tycho Vuurmans JL, Boer WH, Bos WJ, Blankestijn PJ, Koomans HA. Contribution of volume overload and angiotensin II to the increased pulse wave velocity of hemodialysis patients. J Am Soc Nephrol. 2002;13(1):177-83.

11. Chuang SY, Chen $\mathrm{CH}$, Cheng CM, Chou P. Combined use of brachial-ankle pulse wave velocity and ankle-brachial index for fast assessment of arteriosclerosis and atherosclerosis in a community. Int J Cardiol. 2005;98(1):99-105.

12. Brook RD, Brook JR, Urch B, Vincent R, Rajagopalan S, Silverman F. Inhalation of fine particulate air pollution and ozone causes acute arterial vasoconstriction in healthy adults. Circulation. 2002;105(13):1534-6.

13. Rundell KW, Hoffman JR, Caviston R, Bulbulian R, Hollenbach AM. Inhalation of ultrafine and fine particulate matter disrupts systemic vascular function. Inhal Toxicol. 2007;19(2):133-40.

14. Pope 3rd CA, Verrier RL, Lovett EG, Larson AC, Raizenne ME, Kanner RE, et al. Heart rate variability associated with particulate air pollution. Am Heart J. 1999;138(5 Pt 1):890-9

15. Tamagawa E, Bai N, Morimoto K, Gray C, Mui T, Yatera K, et al. Particulate matter exposure induces persistent lung inflammation and endothelial dysfunction. Am J Physiol Lung Cell Mol Physiol. 2008;295(1):L79-85. 
16. Chio CP, Cheng MT, Wang CF. Source apportionment to PM10 in different air quality conditions for Taichung urban and coastal areas. Taiwan Atmospheric Environment. 2004;38(39):13.

17. Langrish JP, Unosson J, Bosson J, Barath S, Muala A, Blackwell S, et al. Altered nitric oxide bioavailability contributes to diesel exhaust inhalationinduced cardiovascular dysfunction in man. Journal of the American Heart Association. 2013;2(1), e004309.

18. Graff DW, Cascio WE, Rappold A, Zhou H, Huang YC, Devlin RB. Exposure to concentrated coarse air pollution particles causes mild cardiopulmonary effects in healthy young adults. Environ Health Perspect. 2009;117(7):1089-94.

19. Heo J, Schauer JJ, Yi O, Paek D, Kim H, Yi SM. Fine particle air pollution and mortality: importance of specific sources and chemical species. Epidemiology. 2014;25(3):379-88.

20. Chen T, Jia G, Wei Y, Li J. Beijing ambient particle exposure accelerates atherosclerosis in ApoE knockout mice. Toxicol Lett. 2013;223(2):146-53.

21. Wang X, Keith Jr JC, Struthers AD, Feuerstein GZ. Assessment of arterial stiffness, a translational medicine biomarker system for evaluation of vascular risk. Cardiovasc Ther. 2008;26(3):214-23.

22. Huang WH, Lin JL, Lin-Tan DT, Chen KH, Hsu CW, Yen TH. Impact of living environment on 2-year mortality in elderly maintenance hemodialysis patients. PLoS One. 2013;8(9), e74358.

23. Michael S, Montag M, Dott W. Pro-inflammatory effects and oxidative stress in lung macrophages and epithelial cells induced by ambient particulate matter. Environ Pollut. 2013;183:19-29.

\section{Submit your next manuscript to BioMed Central and take full advantage of:}

- Convenient online submission

- Thorough peer review

- No space constraints or color figure charges

- Immediate publication on acceptance

- Inclusion in PubMed, CAS, Scopus and Google Scholar

- Research which is freely available for redistribution 